\title{
An External Peer Review of the U.S. Geological Survey Energy Resource Program's Economically Recoverable Coal Resource Assessment Methodology - Report and Comments
}

By U.S. Geological Survey Coal Assessment Team: Timothy J. Rohrbacher1, James A. Luppens ${ }^{2}$, Lee M. Osmonson ${ }^{1}$, David C. Scott ${ }^{1}$ and Philip A. Freeman²

and

Peer Reviewers: Danrick W. Alexander3, Michael A. Berdine4, Michael J. Lincoln ${ }^{5}$, Philip C. Perlewitz ${ }^{6}$, Stanley C. Suboleski ${ }^{7}$, and Gerald A. Weisenfluh ${ }^{8}$

Open-File Report 2005-1076

U.S. Department of the Interior

U.S. Geological Survey

1U.S. Geological Survey, Denver, CO 80225

2 U.S. Geological Survey, Reston, VA 20192

3 West Virginia University, Morgantown, WV 26505

4 Peabody Energy, Twenty-Mile Mine, Oak Creek, CO 80467

${ }^{5}$ Arch Coal, Inc, Western Operations, Hanna, WY 82327

${ }^{6}$ U.S. Bureau of Land Management, Cheyenne, WY 82003

7 Mine Safety \& Health Review Commission, Washington, DC 20001

8 Kentucky Geological Survey, Lexington, KY 40506 


\section{U.S. Department of the Interior \\ Gale A. Norton, Secretary \\ U.S. Geological Survey \\ Charles G. Groat, Director}

U.S. Geological Survey, Reston, Virginia: 2005

For sale by U.S. Geological Survey, Information Services
Box 25286, Denver Federal Center
Denver, CO 80225
For more information about the USGS and its products:
Telephone: 1-888-ASK-USGS
World Wide Web: http://www.usgs.gov/

Any use of trade, product, or firm names in this publication is for descriptive purposes only and does not imply endorsement by the U.S. Government.

Although this report is in the public domain, permission must be secured from the individual copyright owners to reproduce any copyrighted materials contained within this report. 


\section{Contents}

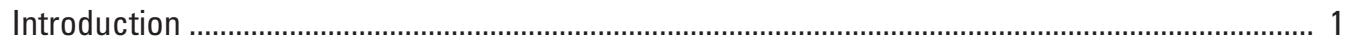

Purpose of the External Review ................................................................................................... 1

History and Goals of the Peer Review.................................................................................... 2

Organization of Report .................................................................................................................... 3

Findings, Conclusions, and Responses to the PRC Report ............................................................ 3

Peer Review Committee Issues and Recommendations ....................................................... 3

USGS/Coal Assessment Team Responses to the PRC Issues and Recommendations ........... 3

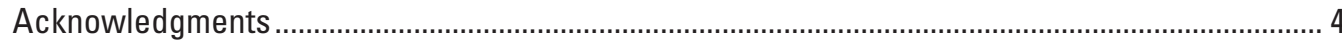

Appendix A - External Peer Review Report of the U.S. Geological Survey Energy Resource Program's Economic Coal Resource Assessment Methodology ........................................ 5

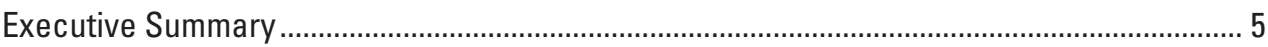

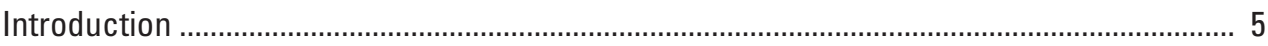

High Level Program Issues [Issues \#1 and \#2] .................................................................... 6

[A] GIS Analysis - Coal Resource Characterization [Issue \#3] .............................................. 7

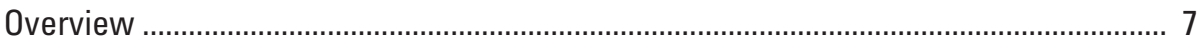

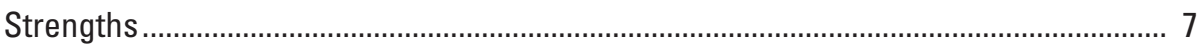

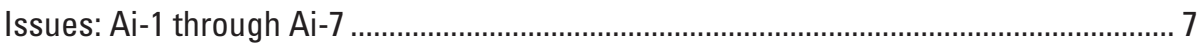

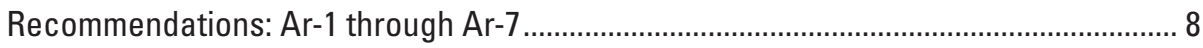

[B] GIS-Mine Modeling Methodology [Issue \#4] ............................................................... 8

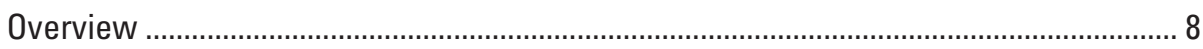

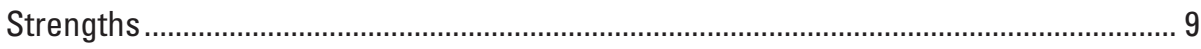

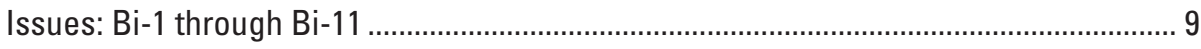

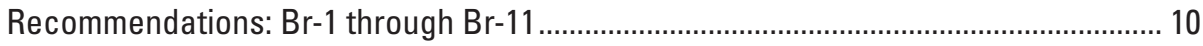

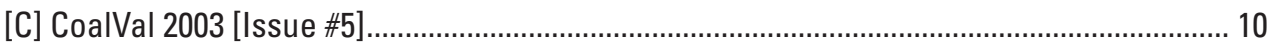

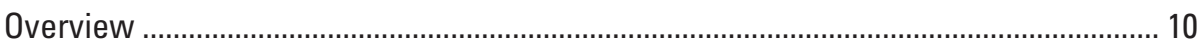

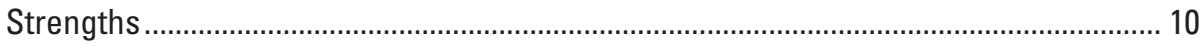

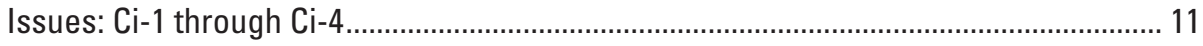

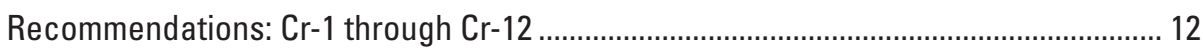

Appendix B - USGS Response to the Peer Review Committee Report.......................................... 12

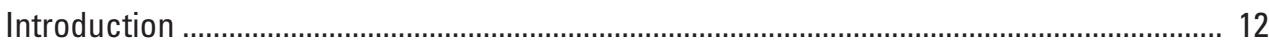

Responses to the PRC Issues and Recommendations ........................................................ 13

Issue \#1 - The Term “Reserves" ................................................................................ 13

Responses............................................................................................................... 13

Issue \#2 - Revision of U.S. Geological Survey's Circular 891 ....................................... 13

Responses.............................................................................................................. 13

Issue \#3 - GIS Analysis - Coal Resource Characterization ............................................ 14

Responses to Ai-1, Ar-2, and Ai-2 - Methods for Reporting and Calculating

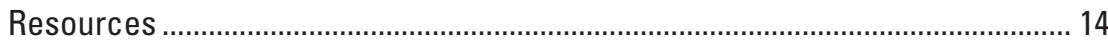

Responses to Ai-3, Ar-2, Ar-6, and Bi-10 - Assessing Reliability and GIS Quality Control 
Responses to Ai-4 and Ar-7 - "Data poor" Areas and Pittsburgh Coal Bed

Modeling .14

Responses to Ai-5, Ar-3, Bi-5, Br-7, Bi-11, and Br-11 - Coal Quality ..................... 15

Issue \#4 - GIS Mine Modeling Methodology ............................................................. 15

Responses to Ai-6, Ar-4, Ai-7, and Ar-5 - Mining Restrictions ............................. 15

Responses to Bi-1, Br-1, and Bi-2 - MINEMODEL Program ............................... 15

Responses to Bi-3, Bi-6, Ci-1e, Cr-12, Ci-1k, Ci-1m, and Cr-2- Mine Modeling

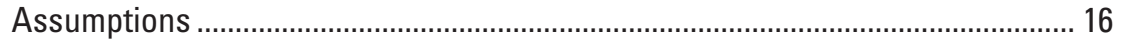

Responses to Ci-4 - Coal Transportation:............................................................... 17

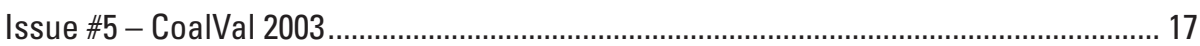

Responses to Bi-9, Br-9, Cr-1, Ci-la, Ci-1g, Cr-8, Br-10, Ci-1h, Ci-1i, Cr-10, Ci-1d, Ci-1f, Ci-1l, and Cr-9 - CoalVal 2003 Cost and Production Assumptions

Responses to $\mathrm{Br}-6, \mathrm{Bi}-7, \mathrm{Br}-7, \mathrm{Bi}-8, \mathrm{Ci}-1 \mathrm{C}, \mathrm{Cr}-11$, Cr-3, and $\mathrm{Ci}-1 \mathrm{~b}-$ Minimum Resource Block Size, Mine Life Assumptions, and Rate-of-Return calculations

Responses to $\mathrm{Ci}-3$ and $\mathrm{Cr}-6$ - Resource-Cost Curve

Responses to $\mathrm{Ci}-2, \mathrm{Cr}-4$, and $\mathrm{Cr}-5$ - Updating Mine Cost and Production

Figures.

Responses to $\mathrm{Bi}-4, \mathrm{Br}-3, \mathrm{Cr}-7, \mathrm{Br}-4$, and $\mathrm{Br}-5$ - Mine Cost Model Additions and Modifications.

References.

Appendix C - Peer Review Committee Biographies.

Danrick W. Alexander

Michael A. Berdine.

Michael J. Lincoln

Phillip C. Perlewitz

Stanley C. Suboleski

Gerald A. Weisenfluh

\section{Figures}

Figure 1. Relation of mine life to recaptured investment 


\title{
External Peer Review of the U.S. Geological Survey Energy Resource Program's Economic Coal Resource Assessment Methodology - Report and Comments
}

\author{
By Timothy J. Rohrbacher, James A. Luppens, Lee M. Osmonson, David C. Scott, and Philip A. Freeman
}

\section{Introduction}

The purpose of this publication is to present, under one cover, (1) the Peer Review Committee's (PRC) External Peer Review Report of the U.S. Geological Survey (USGS) Energy Resource Program (ERP) Economically Recoverable Coal Resource Assessment Methodology, which is a modification of the methodology described in USGS Circular 891 (Wood and others, 1983); and (2) the USGS Coal Evaluation Group (CEG) responses to that report. Papers describing the details of the revised USGS coal resource assessment methodology (Carter and others, 2001, 2002; Rohrbacher and others, 2005), coalfield evaluation studies (Ellis, 2002; Haacke and Rohrbacher, 2005; Luppens and others, 2005; Molnia and others, 2002; Osmonson and others, 2005; Scott and others, 2003, 2005), and the coal resource evaluation program, CoalVal 2003, (Suffredini and others, 1994; McIntosh and others, 2003, 2005) are planned for formal publication after the PRC recommendations have been satisfactorily addressed and modifications made to the current documents.

During the Peer Review wrap-up on the last day of the peer review meetings, the PRC provided the CEG with an outline of their issues and recommendations. This allowed the CEG to immediately begin to address those issues and to develop a plan to research and repair shortfalls in computer programs and databases while the PRC completed and formalized their final report. Many of the issues had been discussed during the Peer Review presentations and were well on their way to being solved, whereas others required mine, company, consultant, and government agency visits to acquire new and updated data. Data were collected during May, June, August, and September of 2004. Computer program and database modifications continue. The CEG has been able to address all of the concerns of the Peer Review and looks forward to providing the PRC and other technical reviewers with revised evaluations of economically recoverable coal resources.

\section{Purpose of the External Review}

One of the key components of USGS operations has been to conduct periodic strategic reviews of all USGS discipline areas as feedback to enhance USGS programs and to make these programs more relevant to the mission of the USGS and to the general public. When significant new or revised energy resource research projects are initiated, the USGS involves industry, academia, and other interested parties by soliciting critical input during the development of the assessment methodologies and procedural elements of our research studies. For example, the National Oil and Gas Assessment (NOGA) was reviewed by a peer group for its assessment methodologies during the 1990s. Similarly, the Eastern Energy Resource Team (EERT) program conducted a strategic review of its operations in 2002. This external review process helps to optimize the relevancy of the USGS programs.

The USGS is in the final stages of its most recent National Coal Resource Assessment (NCRA) project (USGS, 1999, 2000, 2001, 2002; Affolter and others, 2001; Ellis and Nichols, 2001; Pierce, 2001; Rohrbacher and others, 2001; Ruppert and others, 2001). This effort represents the first regional digital assessment of the Nation's coal resources. As the NCRA is nearing completion, plans to begin the next phase of regional coal assessments are already in progress. For this next round of coal assessments, in-place coal resource estimates will not be the primary objective but simply an intermediate step. A key end-component of future coal assessments will be a systematic coal reserve inventory of the significant coal beds in the major U.S. coal basins.

In recent years, there have been many questions regarding the reliability of current estimates of the Nation's remaining coal reserves. In fact, one of the findings of the EERT 2002 external program review was a recommendation to "emphasize the resources that are realistically available for mining and utilization, and just not remaining resources" stating that "there is much confusion about the remaining reserves of coal necessary to meet future fuel supply needs of the United States." Previous regional "reserve" estimates were little more than simple applications of average coal recovery factors to in-place coal resource numbers with little or no real economic 


\section{External Peer Review of the U.S. Geological Survey Energy Resources Program's Economic Coal Resource Assessment Methodology - Report and Comments}

analyses performed. Production amounts were subtracted from the "reserve base" but allowances for mined-out areas, environmental, societal, and technical restrictions to mining, and method of mining (other than surface vs. underground) were not considered. Rapid advances in computer technology and the availability of databases, geographic information systems (GIS) coverages, geological resource models, mine modeling, and mining economics modeling have made the goal of developing a comprehensive coal reserve inventory feasible.

The intent of these reserve analyses has not been to develop detailed mine plans from the limited amount of detailed public information available. The human and financial requirements needed to produce detailed geologic models and mine plans for the Pittsburgh Coal Bed alone would require years of work - regional models of coal stratigraphy and quality, restrictions to mining, and generalized mine and preparation plant recoveries are more logical when assessments are nationwide and the results produce numbers that are relative from one coal region to another.

A key step in the preparation for this reserve inventory task has been the development of mine modeling and mining economics software by the USGS called MINEMODEL and CoalVal 2003. The MINEMODEL program routines use GIS to eliminate coal resources restricted from mining and to produce surface and underground mine models from hierarchical mining assumptions. CoalVal is a menu-driven program that had its beginnings in the U.S. Bureau of Mines; it produces a cost-of-mining analysis of mine-modeled coal resources (prefeasibility level) at a predetermined Rate of Return (ROR). This analysis is done through the use of cost models based on common surface and underground mining methods used in the United States CoalVal can evaluate a large number of coal seams, haulage zones, tax entities, or other area delineations for a given coal property, coalfield, or basin.

\section{History and Goals of the Peer Review}

As the CEG prepared to initiate the next phase of regional coal assessments with the emphasis on remaining coal reserves, it felt that an external review of the program's newly developed coal reserves methodology and tools was needed. Toward this end, the USGS formed the Peer Review Committee (PRC) in early 2004, consisting of a group of six experts with extensive backgrounds in coal geology, mining, management, economics, and resource evaluations (see Appendix C). The purpose of this panel was to provide an independent audit to constructively review the CEG's coal reserve calculation methodology, associated support programs, and results.

During the review meeting, the CEG staff presented the reviewers with the project methodology, demonstrated evaluation programs, and viewed and discussed the results from three regional evaluations: the Pittsburgh bed, four major coal beds in the Illinois Basin, and the Gillette coalfield in Wyoming.
The primary goals of this peer review effort are summarized as follows:

1. To present the USGS's coal reserve calculation methodology and results to a panel of peers experienced in coal geology, mining, management, economics, and resource evaluations,

2. To critically discuss and review the USGS's coal reserve estimation methodology, techniques, and results,

3. To produce a Final Report by the panel with a summary evaluation of the USGS's reserve calculation methodology and include any corrective criticism and suggestions to modify the methodology and reporting formats if appropriate, including:

- Criteria and assumptions for geologic (stratigraphic and coal quality) modeling

- Completeness of the Mine Modeling methodology and approach

- Mining assumptions

- Reasonableness of aggregation procedures from mining production units to county and regional levels

- Additional comments or recommendations

The contributions of this external peer review will not only improve the quality and effectiveness of the USGS coal research program but will play a vital role in generating reliable coal reserve information which will provide a strategic foundational component for future energy planning for the Nation.

The three-day meeting agenda included one day of presentations from the USGS and one and one-half days of reviewer meetings where USGS representatives answered/ explained reviewer questions and the reviewers wrote a rough draft report of their observations. Carolyn Bell, USGS, was the meeting facilitator.

USGS coal resource evaluation staff were given a copy of the original (May 2004) draft report to process, comment on, present supporting information, and outline information-gathering and changes that could be addressed while the committee prepared its final report. Toward that goal, the USGS's CEG worked with the Wyoming BLM, Wyoming State Geological Survey, Gillette Coalfield mining companies, and the consulting firm of Hill and Associates to gather and process data that would address Peer Review Committee questions and comments relative to mining practices and economics in the Gillette Coalfield.

In early August, a CEG engineer visited several underground mines of different size and type and interviewed many coal mine engineers/operators at the International Annual Ground Control Meeting in Morgantown, West Virginia, to better understand increased productivity and mining economics in eastern coalfields.

From May until the present, additional improvements to the CoalVal 2003 program have been completed. Formats addressing PRC input were modified to make the program more user-friendly, subroutines were added to allow automatic updating of CoalVal costs by using the Department of Labor 
Cost of Living Indexes (COLI), redundant parts were eliminated to reduce confusion, and coal quality calculations and outputs were corrected.

\section{Organization of Report}

This report is essentially in two parts, presented in the form of appendixes: (1) Appendix A, which incorporates the report by the PRC that discusses observations and recommendations resulting from its review of the USGS's economic coal resource assessment methodology; and (2) Appendix B, which details responses to the issues raised by the PRC. The final report of the PRC (Appendix A) was divided into three main review areas: (1) GIS analysis - coal reserve characterization, (2) GIS - mine modeling methodology, and (3) CoalVal 2003. In addition to these, two other concerns were raised by the PRC - one regarding definition of the term "reserves" and the other, the need to revise U.S. Geological Survey Circular 891 (Wood and others, 1983). Consequently, we identified five principal issues for which responses were formulated and presented in Appendix B, as follows: Issue \#1, the term "reserves"; Issue \#2, revision of U.S. Geological Survey Circular 891; Issue \#3, GIS analysis-coal resources characterization; Issue \#4, GIS mine modeling methodology; and Issue \#5, CoalVal 2003.

Issues \#3, \#4, and \#5 all contain several parts (sub-issues) and corresponding recommendations that need to be addressed separately. For this reason, we introduced a numbering system to facilitate cross-referencing between these items in Appendix A with our responses in Appendix B. In this system, Issue \#3 is designated with the letter "A," Issue \#4 with the letter "B," and Issue \#5 with the letter "C." With respect to Issue \#3, for an example, individual parts or sub-issues (i) and recommendations (r) are designated Ai-1/Ar-1, Ai-2/Ar-2, and so on, in both Appendix A and Appendix B.

\section{Findings, Conclusions, and Responses to the PRC report}

\section{Peer Review Committee Issues and Recommendations}

The PRC noted that coal is the only primary energy source that can be supplied totally from domestic production. Thus, the regional assessments provide policy makers with critical resource information, a central mission to the USGS and a valuable resource for the Nation. Further, the new coal resource assessment methodology is a significant enhancement over traditional coal resource assessments because it leverages the power of GIS to classify resources by potential mining method and evaluate the economic feasibility of developing those resources. The PRC recognized that the USGS CEG staff has considerable industry experience that benefits the program and that the interdisciplinary composition was commendable.

The main issues identified by the PRC were concerned with establishing and maintaining a knowledge base of coal resource magnitude and characteristics. Regional or basinwide resource assessments are appropriate for the level of detail of this project, and the progression of determining the amount of coal available for mining followed by the amount recoverable through typical mining and processing methods. The PRC recommendations were of two general kinds: those seeking clarification of terminology or methodology, and those addressing model assumptions, especially those applied across regions.

The PRC made the following findings and conclusions:

1. In the opinion of the Peer Review Committee, the USGS is the obvious agency with the capability and motivation to carry out regional and national assessments of U.S. coal resources.

2 . The results of these studies are a significant improvement to existing coal resource estimates, and given the importance of coal in national energy policy, the PRC urges the USGS to expand support for it.

3. Once the regional input database is created, additional "what if" cases could be run using the automated model analysis if a knowledgeable, professional support staff is maintained.

4. The continued federal line-item budget support for this coal resource assessment and recoverability project is recommended in the strongest terms.

5. This project should produce a near-term, accurate picture of U.S. recoverable coal resources.

\section{USGS/Coal Assessment Team Responses to the PRC Issues and Recommendations}

It is important to note that the USGS coal resource assessments deal with regional or coal-field scale approaches, and do not evaluate resources based on a specific propertyby-property evaluation. Consequently, there are trade-offs and limitations to the generalized mine modeling and mine costing of a regional approach vs. the detailed mine planning and mine costing that is tailored to a specific set of conditions or circumstances of an individual property where mining equipment, production, detailed geology, property ownership, etc., are all known.

All of the PRC issues and recommendations were addressed by our responses, as given in Appendix B. Recommendations that required field surveys and data collection were carried out in the summer and fall of 2004, with the assistance of several of the peer reviewers. Mine models were corrected by CEG staff, assumptions were updated from mine and consultant interviews, and computer programs were modified to meet PRC observations and recommendations. The 
changes made, or commitments to change, are reviewed in detail in Appendix B.

\section{Acknowledgments}

We would like to thank all members of the Peer Review Committee (Appendix C) and their employers for the time and efforts needed to prepare for their review by examining project summary documents sent to them prior to the Denver meetings. The CEG group greatly appreciated the review committee's attention to details and resulting questions during presentations regarding the detailed project methodology, complex computer programs, and coal resource evaluation results; the development of an outline of issues and recommendations in $2 \frac{1}{2}$ days of meetings; and the follow-up efforts to produce a summary report.

Special thanks are due to Jerry Weisenfluh of the Kentucky Geological Survey for coordinating the peer review report and assembling the final report document, and to Dan Alexander for his report writing and editing. Thanks are also due Dan Alexander and Syd Ping of the Mining Engineering Department at West Virginia University for arranging Northern Appalachian mine visits and for their assistance in collecting mine production and economics data. Philip Perlewitz and his staff at the Wyoming BLM, Robert Burnham at Hill and Associates, and Gregg Bierei and his staff at the Black Thunder Mine provided valuable assistance in reviewing Gillette Coalfield economics, mine operations, and mine planning and designs.

Finally, the CEG would like to extend thanks to Carolyn Bell, USGS, for her outstanding guidance as Review Meeting Facilitator. 


\section{Appendix A}

\section{External Peer Review Report of the U.S. Geological Survey Energy Resource Program's Economic Coal Resource Assessment Methodology}

\author{
By ${ }^{1}$ Danrick W. Alexander, Michael A. Berdine, \\ Michael J. Lincoln, Phillip C. Perlewitz, \\ Stanley C. Suboleski, and Gerald A. Weisenfluh
}

\section{Executive Summary}

Based on a two-day review and supporting documentation, a Peer Review Committee (PRC) comprised of representatives from industry, government, and academia found the U.S. Geological Survey (USGS) Coal Reserve Evaluation program to be a valuable resource for the nation. Conducting regional assessments that require compilation of information across state boundaries has always been an important role for the USGS, and providing these assessments to policy makers is central to the mission of the Survey. This methodology, originally developed at the U.S. Bureau of Mines and extended by the USGS, is a significant enhancement over traditional coal resource assessments. It leverages the power of GIS to classify resources by potential mining method and takes into account an extensive database of mining and processing costs to evaluate the economic feasibility of developing those resources. The USGS staff has considerable industry experience that benefits the program. The PRC commends the USGS for continuing to improve the method, given the limited resources of the program.

The following sections of this report give an overview of the program, and discuss the three main components of the method: 1) coal resource assessments, often done in cooperation with state geological surveys, 2) mine modeling (MINEMODEL), and 3) economic evaluation of mine blocks (CoalVal). For each part, issues and concerns were identified and recommendations are given to strengthen the program. Recommendations were of two general kinds-those seeking clarification of terminology or methodology and others addressing model assumptions, especially those applied across regions. The former can be easily addressed in program documentation and reports. The latter, in many cases, may require updating supporting information.

Two high-level issues emerged during the review. The first concerns the use of the term "Reserves" in the program

1 See Appendix C for affiliations and biographical data. name. Panel members felt that this could be misleading to end users who may assume that the method is comparable to that used in industry for site specific mine planning. Language should be chosen to clearly distinguish this methodology from coal resource estimates and industry mine planning. The second was a concise documentation of program assumptions and support data. It was not feasible in the allotted time to evaluate every model assumption, but a number of examples surfaced that did not appear to be consistent with current practice, at least for some geographic areas. The underlying database of model parameters is a valuable resource in of itself, and making these data more accessible may ultimately benefit the program.

The PRC recognizes that some of the recommendations contained in this report may not be feasible with existing program resources. The results of these studies are a significant improvement to existing coal resource estimates, and given the importance of coal in national energy policy, we urge the USGS to expand support for it.

\section{Introduction}

The Energy Resource Program (ERP) of the U.S. Geological Survey (USGS) is nearing completion of a phase of the National Coal Resource Assessment (NCRA), which will result in a digital assessment of the United States' productive coal resources on a regional basis. The next phase of the NRCA project, which has already been initiated, is the development of a standardized approach for the assessment of economic feasibility of extracting coal resources. The USGS's evaluation of the Nation's economically recoverable coal resources grew from concerns regarding the usefulness of current estimates of the remaining coal resources necessary to meet the future fuel supply needs of the United Sates. Thus, the economic coal resource assessment methodology was developed and incorporates the use of mine-type modeling (MINEMODEL) and mining economic analysis (CoalVal) software developed by the USGS.

Currently, three coal basins within the United States have been partially evaluated using the methodology and software developed by the USGS. Economic coal resource evaluations have been performed for the following areas: the Pittsburgh coal bed in the northern Appalachian basin; the Springfield, Herrin, Danville, and Colchester beds in the Illinois Basin; and the Wyodak/Anderson coal zone of the Gillette Coal Field in the Powder River Basin in Wyoming.

The USGS convened an external review panel whose members have an extensive background in coal geology, mining, management, economics, and resource evaluation. The team was to provide an independent and constructive review of the ERP's coal resource assessment methodology, associated support programs, and results. This report constitutes the report of the panel.

From May 11th through May 13th of 2004, the review panel met at the USGS's office in Denver, Colorado to conduct 
External Peer Review of the U.S. Geological Survey Energy Resources Program's Economic Coal Resource Assessment Methodology - Report and Comments

their review. The review team comprised of: Danrick W. Alexander, Michael A. Berdine, Michael J. Lincoln, Stanley C. Suboleski, Gerald A. Weisenfluh, and Phillip C. Perlewitz.

\section{High Level Program Issues [lssues \#1 and \#2]}

In the opinion of the Peer Review Committee (PRC), the USGS is the obvious agency with the capability and motivation to carry out regional and national assessments of US coal resources. Coal is the only primary energy source that can be supplied totally from domestic production and thus establishing and maintaining a knowledge base of the coal resource magnitude and characteristics is critical to industry and government policy decisions.

Regional or basin-wide resource assessments are appropriate for the level of detail of this project using state generated geologic data and current geospatial modeling technology. The progression of determining COAL AVAILABILITY followed by RECOVERABILITY or CAR is logical and provides intermediate results adequate for different stakeholder uses. The interdisciplinary composition of the USGS resource assessment staff is commendable and their varied experience will contribute to wide acceptance of the final product.

It is beyond the scope of this evaluation to speculate on how this assessment information will be applied. However, it is appropriate for the USGS to design the assessment in such a way that anticipated policy questions and issues, to which the USGS has contributed factual information in the past, could be quickly addressed in the future. Once the regional input database is created (which is a major accomplishment in itself, resulting from a large investment by state geologic surveys and federal agencies) additional "what if" cases could be run using the automated model analysis if a knowledgeable, professional support staff is maintained. The continued federal line item budget support for this coal resource assessment and recoverability project is recommended in the strongest terms. Such a dedicated staff would also be able to perform revisions of methodology to account for new mining methods and technology improvements and to revise productivity assumptions as needed to extend the shelf life of the assessment.

The PRC has agreed on several preliminary recommendations and observations identified in this report. We understand that this assessment methodology is not an attempt to exhaustively inventory all known coal in the US, but is designed to assess coal recoverability from seams that produce $90-95 \%$ of all coal. Pending the results of verification of the methodology, this project should produce a near term, accurate picture of US recoverable coal resources.

The term "reserves" is used in the project documentation in a colloquial manner, common to the coal industry, whereas when the term is used in an SEC filing or project-financing proposal, it has a very specific meaning. For a deposit to be classified as a reserve, it must be evaluated with respect to a specific mine plan for economic viability by a qualified person who determines to a reasonable certainty that the resource is "economically and legally recoverable using current technology" at that point in time. The USGS assessment does not purport to meet this threshold of diligence. It is recommended that "economically recoverable coal resources" or similar term be adopted for this project and the term "reserve" be used only in its strictest definition to avoid confusion. [Note: The topic of "reserves" is treated as Issue \#1 in Appendix B]

The cost estimating module produces a single deterministic value; however, cost estimates are recognized to have a confidence level corresponding to the engineering accuracy of the assessment. A pre-feasibility cost estimate, such as that produced by the CoalVal model, is typically plus or minus $25 \%$ accuracy. Therefore, the realization required to generate a specified financial rate of return based on those cost distributions will exhibit a range of values converging on an expected value. Economically recoverable resources should be presented within a confidence interval to show the underlying uncertainty of a regional pre-feasibility assessment.

In addition, CoalVal uses a time interval, to evaluate each mining method cost, which is shorter than would normally be required to recover the investment and maximize the return. It then projects this cost over the entire reserve. Figure 1 shows that only $60 \%$ of the Net Present Value (NPV) is recovered for a 10-year project, the time interval specified for a Logical Production Unit (LPU). This methodology may thus introduce an inherent bias into the model results.

The assessment methodology requires many assumptions for each mining method and region. Regional or basin peer review meetings would provide an opportunity to evaluate current cost models and gather additional cost and operational data for the model inputs. This process would provide an opportunity to build credibility for the USGS product and gain current best practice data for the estimates. Although the project team and the PRC members have wide ranging experience,

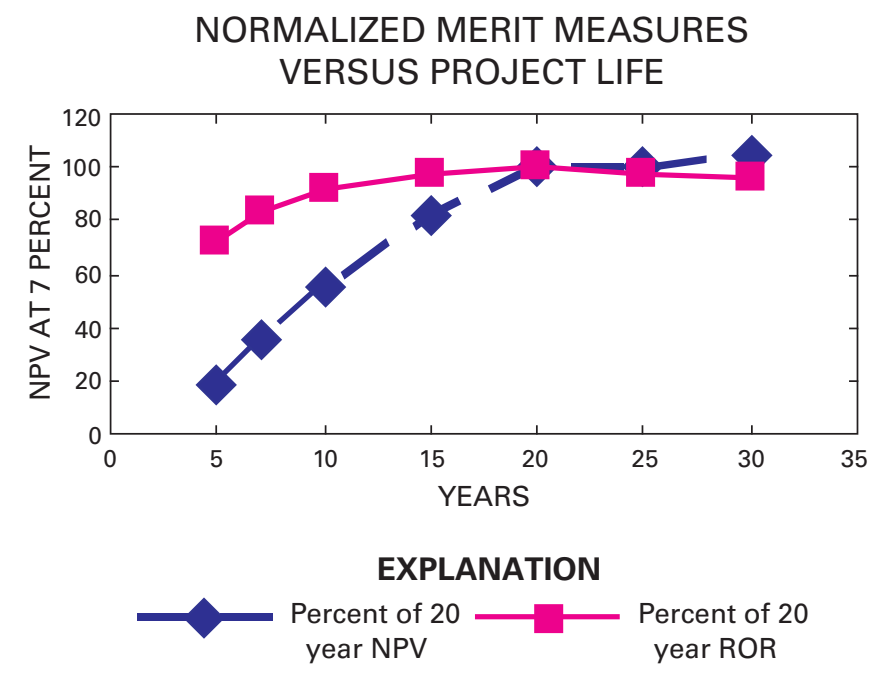

Figure 1. Relation of mine life to recaptured investment. 
it is insufficient to properly characterize each coal-producing region.

One issue that must eventually be addressed is the revision of 1983 Geological Survey Circular 891, "Coal Resource Classification System of the U. S. Geological Survey". The bulletin applies a single criterion to classify geologic resources for the entire country into measured, indicated and inferred confidence intervals. Users of these data need to know the reliability of the estimates published by the USGS. It is recommended that, because regional differences are significant and impact the geospatial distribution of sample data required for each confidence level, regional resource classification criteria should be clearly defined and documented. [Note: Revision of Geological Survey Circular 891 is treated as Issue \#2 in Appendix B]

\section{[A] GIS Analysis - Coal Resource [Issue \#3 in Appendix B]}

\section{Overview}

This section deals with the methodology of preparing resource calculations that form the basis for mine modeling and subsequent valuation. Regional maps of coal outcrop, seam height, parting thickness, and coal elevation are prepared to characterize individual, mineable coal beds. Surface elevation models are employed to evaluate the accessibility of coal by specific mining methods. In most cases, state geological surveys prepare the resource information through cooperative projects with the USGS; otherwise USGS staff conducts the entire assessment. States are given considerable latitude in methods of data treatment and resource characterization, but in general, the methodologies of USGS Circular 891 are followed.

One critical difference between coal resource methodologies specified in Circular 891 and those of this program concern the treatment of seam impurities. Whereas traditional in-place coal resource estimates are prepared on a net or coal-only basis, this program calculates potentially mineable original resources to include rock partings, then applies a mining and processing analysis to include out-of-seam dilution and reduce the tonnages by estimated recovery percentages for specific mining methods. Another difference is that Circular 891 specifies 14-in net thickness categories for bituminous coal, whereas this methodology uses 12-in gross increments. Categories for subbituminous coal for both methodologies begin at 2.5 to 5 feet, 5 to 10 feet and then follow multiples of $10 \mathrm{ft}$.

In addition to original resource information, mined-out areas are documented to determine remaining coal. Further, coal availability methodologies are employed to quantify legal, societal, environmental, and technological restrictions to mining that are anticipated. These data are prepared in GIS format so that the original, remaining, and available resource volumes can be calculated and used as a basis for a variety of recoverability and valuation studies.

\section{Strengths}

The PRC feels that the approach of modeling coal on a regional basis is a valuable technique, provided that the limitations of publicly-available data are adequately described. Users need to be informed about the distinctions of such regional modeling compared to a reserve assessment that would be conducted at the property scale, where site-specific mine plans are developed. The GIS approach is ideal for conducting an analysis of this type, and the specific form of GIS analysis (i.e., cell-based modeling) used by the USGS is consistent with standard practices. The USGS should be commended for developing software tools that provide considerable automation, and achieve efficiencies that make such an ambitious program feasible, given limited resources.

\section{Issues [Ai-1 through Ai-7]}

[Ai]-1. There is general concern that the different reporting methods for resources (coal only versus total seam) may be confusing to end users. For the task of quantifying in-place resources, the coal-only method specified in Circular 891 is probably adequate for the purposes the data are used for. But the total seam basis used in this methodology is more indicative of how coal is ultimately extracted, processed, and delivered to market. It is unclear, though, whether sufficient data are used to assess coal recovery on a regional basis. The primary data used are parting thickness information from state databases, but it is doubtful that adequate site-specific washability analyses have been incorporated into the assessment. [See USGS comments Issue \#3 for response.]

[Ai]-2. Additionally, the different thickness categories used in these methodologies make it difficult to compare original resource estimates to those of recoverability studies. For example under Circular 891 the 14-in net thickness plus the maximum $50 \%$ parting is equal to 14 to 21 -in thickness for the coal bed. The 12-in bed thickness used currently may include up to $50 \%$ parting which is equal to 6 to 12 -in net coal thickness under Circular 891. Clearly the new reporting method will show a much larger original coal resource volume. This may be desirable where new mining methods warrant including thinner seams in the resource base. [See USGS comments Issue \#3 for response.]

[Ai]-3. The PRC is concerned about uncertainties in the original resource estimates that relate to data distribution and quality, because these estimates are the foundation of all subsequent analyses. Any regional assessment will have highly variable data control to characterize the in-place resource. There was general agreement that the Circular 891 methods of quantifying uncertainty (reliability arcs of the same dimension for all regions) are inadequate because they do not take into account rates of lateral variation for different coal beds. 


\section{External Peer Review of the U.S. Geological Survey Energy Resources Program's Economic Coal Resource Assessment Methodology - Report and Comments}

It is accepted that these uncertainties exist, but they need to be incorporated into the model using a better methodology and documented clearly. [See USGS comments Issue \#3 for response.]

[Ai]-4. Areas not assessed due to lack of data (e.g., the Pittsburgh coal bed in Central West Virginia) are problematic because of the potential impact they might have upon the final analysis. We agree that they should not be assessed using the same methodologies as those of beds with adequate data, but some description of what is known about the potential resource is needed to place the areas in a proper context. [See USGS comments Issue \#3 for response.]

[Ai]-5. There is agreement that insufficient coal quality data are publicly available to prepare spatial estimates of variation comparable to coal thickness. Yet this is a critically important variable in the GIS analysis for determining economic mineability, since quality is the primary indicator for pricing the product. [See USGS comments Issue \#3 for response.]

[Ai]-6. Given the uncertainty about accuracy of location and completeness of underground mine maps, the PRC believes that the barrier distance used in this methodology is too small. [See USGS comments Issue \#4 for response.]

[Ai]-7. The PRC believes that many of the restrictions to mining, especially those related to land-use, are routinely mitigated. It is understood that state personnel generally use local knowledge to make prudent decisions concerning which restrictions should apply, but there is little documentation about how those decisions were reached. Moreover, some of these restrictions, while being insignificant in terms of tonnage, may have an important impact on the delineation of mine areas in subsequent parts of the modeling. Some restrictions are prohibitions to mining and others are limits to subsidence but it is unclear how these distinctions impact the size of the available mining block or the mining method ultimately chosen for an area. [See USGS comments Issue \#4 for response.]

\section{Recommendations [Ar-1 through Ar-7]}

[Ar]-1. Use of whole-seam basis for tonnage estimates with subsequent recovery analysis is justified in this methodology. To minimize confusion with coal-only estimates, it is suggested that both be reported (and clearly identified), so that users can compare the results of the two. Final products for this program should contain relevant maps for each basis, as well as tabular results. The use of different thickness categories makes such comparisons difficult, however. Given the current prevalence in the East of mining coals with significant parting material and the West with little parting, the USGS should revise its guidelines for coal resource estimates specified in Circular 891 to better characterize seam impurities. This should be undertaken in consultation with state surveys and should have some basis in seam-specific washability data. [See USGS comments Issue \#3 for response.]
[Ar]-2. Revise methods of assessing reliability of the estimate specified in Circular 891 to take into account lateral variation of individual coal beds.

[Ar]-3. Develop a long-term strategy for assessing coal quality parameters on a regional basis. Gain knowledge of how much data would be needed to make this assessment and identify means of collection or obtaining such data. [See USGS comments Issue \#3 for response.]

[Ar]-4. It is suggested that the $50 \mathrm{ft}$ buffer distance for underground mines be increased to at least 150 or $200 \mathrm{ft}$. [See USGS comments Issue \#4 for response.]

[Ar]-5. Establish better guidelines for making decisions about what restrictions to mining should be used in a given area, and for documenting those decisions. [See USGS comments Issue \#4 for response.]

[Ar]-6. Perform some type of post-GIS quality control to determine if errors in placement of resource categories introduced by map resolution and grid re-sampling are within acceptable limits. [See USGS comments Issue \#3 for response.]

[Ar]-7. Provide some description of what is known about large potential resources, such as the Pittsburgh seam in Central West Virginia, to place the areas in a proper context [See USGS comments Issue \#3 for response.]

\section{[B] GIS - Mine Modeling Methodology [lssue \#4 in Appendix B]}

\section{Overview}

The second phase of the coal reserve evaluation methodology reviewed by the PRC involves the process whereby available coal resources are converted into quantified, potentially mineable resources using ESRI's ArcView Spatial Analyst through the USGS's MINEMODEL program. This has been referred to as "auto-planning" and is accomplished through a computer analysis of gridded data for the coal resources that are available to be mined (as generated in the initial GIS analysis) utilizing a hierarchy of assumptions to arrive at the most appropriate potential mining method. Parameters that are assessed in this analysis include variables such as: seam thickness, topographic slope, coal bed dip, overburden thickness, and stripping ratios. After the mining methods have been defined, tonnages associated with each mine type are assigned to a hypothetical "mine model". Further computer analysis is done to the mine model in order to determine whether the size of the potentially mineable resource meets the minimum tonnage and spatial requirements (as defined for each mining method) that are necessary to warrant "greenfield" development of the resource. Upon meeting the minimum size criteria, these tonnage blocks, which are referred to as Logical Production Units (LPUs), are analyzed for any tax, royalty, or transportation issues that are applicable to the 
location of the reserves. Once all spatial analyses have been completed, the numeric mine model results are then exported for use in the economic evaluation phase of the assessment project.

\section{Strengths}

Methodologies utilized in this phase of the process provide an efficient means of dealing with the large array of potentially mineable resources found throughout the country. Due to the flexibility provided by the auto-planning analysis techniques, adjustments to mining assumptions can be made in order to accommodate newly legislated restrictions to mining, or conversely, advancements in mining technology, which may result in the ability to mine coal resources that were previously considered unmineable. Resultant changes to the mineable resources are thus more readily attainable than techniques using mine plans that are carried as discrete, geospatially delineated areas. Additionally, the ability to customize mining assumptions provides an opportunity to accommodate the inherent differences in coal resources found between the various coal basins and regions. The GIS environment allows all geospatial data to be displayed in map form for interpretation and better understanding of the process used.

\section{Issues [Bi-1 through Bi-11]]}

[Bi]-1. The hierarchy utilized in the auto-mining methodology for the basic mining methods is well documented; however, it has not been conveyed sufficiently to understand the process where complicated incremental ratio calculations, highwall mining, or dragline vs. truck/shovel decisions may be involved. [See USGS comments Issue \#4 for response.]

[Bi]-2. Although hybrid-mining assumptions may be beyond the scope of a basin wide approach to the methodology, there are instances, such as pre-stripping for dragline mining, where it may have enough of an effect on projected mine costs, even at this level of accuracy, that it should be incorporated in the model. [See USGS comments Issue \#4 for response.]

[Bi]-3. All of the mine models assume that the remaining coal resources are associated with new mine development and discount the ability to expand existing operations with tonnages that are less than the minimum required to delineate a Logical Processing Unit for each of the various types of mining. Not only will some of the mineable resources be eliminated, but also more importantly, capital costs associated with mine startup will be incorrectly applied to tonnages that are incremental to developed mines and will increase the reported cost of those tons. The panel members recognize that, because these are being mined or are adjacent to the area being mined, it is likely that they are the lowest cost reserves and their position on the supply curve will remain relatively the same if they are part of an LPU. [See USGS comments Issue \#4 for response.]
[Bi]-4. All Eastern coal is assumed to be trucked to existing preparation plants, however, the larger blocks of coal may warrant building new preparation and loadout facilities. It is not likely that longwall mine production will be trucked, both because their reserve base is sufficiently large to amortize a plant, and their daily output is large enough to make trucking infeasible. Blocks of coal adjacent to existing mines will most likely be moved by belt conveyor. [See USGS comments Issue \#5 for response.]

[Bi]-4. All Eastern coal is assumed to be trucked to existing preparation plants, however, the larger blocks of coal may warrant building new preparation and loadout facilities. It is not likely that longwall mine production will be trucked, both because their reserve base is sufficiently large to amortize a plant, and their daily output is large enough to make trucking infeasible. Blocks of coal adjacent to existing mines will most likely be moved by belt conveyor. [See USGS comments Issue \#5 for response.]

[Bi]-5. There are significant differences in coal quality within the Gillette and Pittsburgh coalfields that have not been modeled. The model does not reflect the real difference in the sales price for the differing coal qualities. [See USGS comments Issue \#3 for response.]

[Bi]-6. It has been assumed that the seams are to be mined from the topmost seam down. In practice, this is manifested through the assumption that all deep-mined seams separated by more than 40 -feet of interburden would be recovered. It is unrealistic to assume that mining will be done in a sequence that best recovers all mineable resources. The most economical underground mineable seam can generally be expected to be mined first (usually the thickest or best quality seam) and although there are documented cases of successfully recovering seams that have been undermined within reasonably close proximity, the thicker the initially extracted seam is, the less likely it will be to recover overlying seams of lesser thickness if high extraction mining was conducted. This may depend on local practice, the time between mining or on the interburden geology. [See USGS comments Issue \#4 for response.]

[Bi]-7. The minimum size of a mining block (LPU) for each mining type appears to be set at an arbitrary value. The effect this size may have on "lost" potentially mineable resources or increased cost of the next-best mining method is not known. [See USGS comments Issue \#5 for response.]

[Bi]-8. The uniform assumption for minimum mineable block size for all basins may not reflect regional differences in property ownership and development strategies. [See USGS comments Issue \#5 for response.]

[Bi]-9. Areal recovery assumptions appear to be overly optimistic for longwall, continuous miner, and highwall mining techniques. While a recovery is given for highwall mining, a highwall mining cost model has yet to be developed. This technique is gaining in popularity, and is displacing auger mining, though the extent or rate of the displacement is not known. [See USGS comments Issue \#5 for response.] 
[Bi]-10. Estimates of the mineability of coal resources in areas of steeper slopes is highly sensitive to the accuracy and resolution of the gridded topographic and structural data, therefore the mineable coal resources available for contour mining, and any associated highwall mining, are likely to be the least reliable. [See USGS comments Issue \#3 for response.]

[Bi]-11. It is not clearly documented how much data are used for the county averages of coal quality, and use of data on an as-received basis may impede comparisons between regions. [See USGS comments Issue \#3 for response.]

\section{Recommendations [Br-1 through $\mathrm{Br}-11]$}

[Br]-1. Clarify and document the hierarchy of the more complicated auto-planning scenarios. [See USGS comments Issue \#4 for response.]

[Br]-2. Determine whether hybrid-mining methods need to be modeled. That is, determine whether (or under what conditions) such cost models are sufficiently different that a separate model is warranted. [See USGS comments Issue \#4 for response.]

[Br]-3. Consider the addition of the highwall mining method as an alternative to or replacement for auger mining. [See USGS comments Issue \#5 for response.]

$[\mathrm{Br}]-4$. Consider adding the ability to expand existing mines into the auto-planning capabilities for areas where suitable expansion is feasible (consider this on a regional basis where possible). Although some knowledge of coal ownership would seem to be required to accomplish this, the present methodology already assumes ownership cooperation. It is recognized that it may not be feasible in areas such as Central Appalachia, where there are many hundreds of mines in operation. However, in the Pittsburgh and Gillette basins, a haulage radius from the existing plant may be sufficient to define a logical mining unit. These adjacent areas could be displayed on the basin mapping. [See USGS comments Issue \#5 for response.]

$[\mathrm{Br}]-5$. Review the methodology for including trucking distances to determine if this complex method is desirable, particularly in the case of longwall mines. [See USGS comments Issue \#5 for response.]

[Br]-6. Consider an option which would allow the creation of mining blocks (LPUs) that are of sufficient size (singly or in local groups) to justify capitalizing new preparation and/or loadout facilities. [See USGS comments Issue \#5 for response.]

[Br]-7. Subdivide the Gillette coalfield to accommodate the 8400 BTU vs. the 8800 BTU quality differences. Subdivide the Pittsburgh basin into high ash, Ohio River mines and low ash rail mines. [See USGS comments Issue \#3 for response.]

[Br]-8. Conduct sensitivity analyses on minimum block sizes (LPUs) for each major mining type within each coal basin, in order to minimize potentially lost coal resources. [See USGS comments Issue \#5 for response.]
[Br]-9. Review mining methods and assumptions and adjust these as needed by coal producing basins or regions. Feedback should continue to be sought from local industry concerning mining methods and operational criteria, perhaps in the form of individual meetings for each one of the basins to ground-truth the mining methods and assumptions. [See USGS comments Issue \#5 for response.]

[Br]-10. Clarify how areal recoveries are calculated and provide a weight average mine wide recovery number for each mining method. [See USGS comments Issue \#5 for response.]

[Br]-11. Quantify the data distribution for coal quality by county, so that users understand the uncertainties of these assessments. Use a moisture-free reporting basis for model development, including moisture content as a separate variable where appropriate. [See USGS comments Issue \#3 for response.]

\section{[C] CoalVal 2003 [Issue \#5 in Appendix B]}

\section{Overview}

CoalVal is a coal resource evaluation program originally developed by the U.S Bureau of Mines (CoalVal - Plis and others, 1994; CoalVal 2.0 - Suffredini and others, 1994) and recently modified and improved by the U.S. Geological Survey (CoalVal 2003) to handle large quantities of cost data associated with coal resource evaluations. The program is designed to directly receive resource estimates from ArcView Spatial Analyst and ultimately produces a pre-feasibility level, cost-of-mining analysis for selected mining methods. USGS staff presented an overview of the program to the PRC. The PRC was also provided with a draft copy of the CoalVal program and Coal Resource Evaluation Methodology for further review and critical discussion. Several demonstrations of CoalVal were also made by the USGS staff for specific mining situations that were hypothesized by members of the PRC. Comments and suggestions resulting from the overview and subsequent discussions are summarized as follows:

\section{Strengths}

The PRC feels the program is a valuable tool for producing pre-feasibility level, cost-of-mining analysis of regional coal resources, provided the reasonableness of the various mine model assumptions/values is verified. The analysis is done through the use of cost models designed for the common surface and underground mining methods used in the U.S. To date, cost models have been developed for several mining regions (e.g. Northern and Central Appalachian Basins, Illinois Basin, Powder River Basin, etc.) and will evaluate an unlimited number of coal seams, haulage zones, tax entities or other area delineations for a given property, coal field or basin. Coal resource and quality data is imported and either default values for production, operating and cost variables are input 
or may be overridden by the user. The end result is a summary report of the total cost of recovering all the available and mineable resource LPU blocks in the area. The economically recoverable resources remaining in any given coal field or basin are identified by comparing these costs to the assumed area realization. The program does this by first calculating the total (operating, capital and return on investment) cost of mining for a new mine, using the most logical mining method in each LPU, which in turn is used to produce a supply curve. An estimate of the economically recoverable coal tonnage is based on the intersection of the threshold price for each resource area and the supply curve. The cost of capital invested is recouped by discounting future cash flow.

\section{Issues [Ci-1 through Ci-4]}

[Ci]-1. The PRC found numerous cases where model assumptions were not consistent with current practices and knowledge. Several key examples (but not a complete itemization) are as follows:

a. CoalVal is a complex model that, because it is so intimately integrated into the GIS portion of this effort, is difficult to evaluate independently in a short period, such as this evaluation. The two tests that were conducted tended to indicate that the current default data in the model greatly underestimates the ton-per-unit-shift productivity and overestimates the needed manpower. In view of the average 6-percent-per-year increase in labor productivity in the coal industry over the two decades following the low point in 1978, non-current data in the model would produce the effect observed (i.e., lower productivity and higher manpower). [See USGS comments Issue \#5 for response.]

b. Because CoalVal produces a pre-feasibility estimate on cost that is not based on either a physical mine plan or detailed local geology, a single number cost may mislead users regarding the accuracy of the estimate. Unbiased, pre-feasibility models are generally accepted as having a plus or minus $25 \%$ accuracy and displaying such a range of costs may give the user a better feel for the range of the "correct" answer. [See USGS comments Issue \#5 for response.]

c. The ten-year "snapshot" of costs used by CoalVal is likely producing biased cost estimates, as explained earlier. The typical project life for a new mine depends on the profit margin and Discounted Cash Flow - Rate of Return (DCF ROR) hurdle rate acceptable to the investors. CoalVal defaults to a $10 \%$ ROR to calculate the realization required to mine a resource block. The normalized example charted on page 3 shows that approximately $55 \%$ of the 20 year project NPV and $92 \%$ of the ROR is attained in 10 years. [See USGS comments Issue \#5 for response.]

d. For longwall mines, the percentage of continuous miner tons (31-34\%) in the longwall to continuous miner ratio is too high. The longwall to continuous miner tonnage ratio is typically in the range of $80-90 \%$ longwall to $10-20 \%$ continuous miner unless CMs are used in production in the same mine. [See USGS comments Issue \#5 for response.] e. It is not clear what the definition of "Mineable Resource Recovery" is. Is this the area recovery rate? [See USGS comments Issue \#4 for response.]

f. As intimated above, the longwall productivity rates for the Pittsburgh seam are too low. The program documentation does not explain how the productivity rates are established for the various types of mining. [See USGS comments Issue \#5 for response.]

g. It appears that maintenance and production downtime is built into the productivity rates. If not, this provision would need to be added for the various mining methods. [See USGS comments Issue \#5 for response.]

$\mathrm{h}$. The provision to manually input operational supplies are expressed in units (cost per hour) that are not familiar to underground coal mine operators. It is not apparent how the maintenance-materials assumptions are entered or accounted for in the program. [See USGS comments Issue \#5 for response.]

i. Preparation plant costs in the East and rail load out costs in the Powder River Basin appear to be excessive. [See USGS comments Issue \#5 for response.]

j. It appears that arbitrary numbers have been assigned to the recovery components in the mine model assumptions. [See USGS comments Issue \#4 for response.]

$\mathrm{k}$. Most contour surface mines in the eastern US either do not clean their coal or clean only a small fraction of the coal. To the extent that this coal is assumed to be sent to a processing plant, the cost estimate will be too high. In surface mines in the eastern US, partings (perhaps, those in excess of six inches) are separated from the coal and not shipped to the plant. [See USGS comments Issue \#4 for response.]

1. CoalVal does not report the productivity (saleable tons per man-hour worked) that it calculates for each mining method. Both the EIA and MSHA report productivity at individual mines on an annual or quarterly basis - unlike costs, which are rarely reported. Productivity could serve as a reasonableness check. [See USGS comments Issue \#5 for response.]

m. Many of the other assumptions appear to be reasonable, but are obviously critical to the accuracy of the models. While the PRC could make some recommendations for the various assumptions, these need to be verified on a regional/ basin basis. The assignment of final values to these and other key assumptions should therefore be verified by regional/basin meetings with industry people. [See USGS comments Issue \#4 for response.]

[Ci]-2. The inherent nature of economic models is that they become quickly outdated as both prices and technologydriven costs continually change. Each mining type in CoalVal will require updating before the regional economic resources can be re-evaluated in the event, for example, of a change in productivity. While CoalVal is the model of choice in the current study, it is a complex model and the work involved in updating the model is proportional to the complexity. [See USGS comments Issue \#5 for response.] 


\section{External Peer Review of the U.S. Geological Survey Energy Resources Program's Economic Coal Resource Assessment Methodology - Report and Comments}

[Ci]-3. Because CoalVal cannot take variations in local geology - nor equipment or management techniques - into account, and because of other necessary simplifying assumptions, it produces a supply curve that shows less variation (i.e., is "flatter") than actual curves. As a result, in a given basin, more of the economically mineable resource by a single type of mining will either tend to be included or excluded from the economic reserve base at a given price than will occur in reality (i.e. the methodology makes the economically mineable resource estimate very sensitive to small realization changes or supply is very elastic). This is illustrated in the supply curve for the Pittsburgh seam, where an increase in price of less than $\$ 2$ per ton raises the recoverable resource from 1.7 to 7 billion tons. [See USGS comments Issue \#5 for response.]

[Ci]-4. In the East, CoalVal assumes that all mines in a county will clean their coal by trucking production to an existing processing plant, and that the trucking distance will extend along public roads from the middle of the county to the nearest plant, regardless of the location of the reserve. For longwall areas, with a minimum reserve requirement of 45 million tons (the same is true of similar large contiguous-tonnage areas), it is unlikely that the coal would be trucked, as noted above. Given the assumptions for determining trucking distances, it is not clear that the determination of the fictitious routes along actual roads is worth the complexity. Pittsburgh Seam longwall mines are currently permitting underground and overland conveyor haulage distances greater than 13 miles or 70,000 feet. [See USGS comments Issue \#4 for response.]

\section{Recommendations [Cr-1 through Cr-12]}

[Cr]-1. Verify the reasonableness of the assumptions for the different types of mining by initiating a separate industry review process on a regional/basin basis. Many of the following recommendations may be included in the review process but are listed separately here for clarity. [See USGS comments Issue \#5 for response.]

[Cr]-2. Consider studies of additional sensitivity on reserve estimates and costs, since the results of any model run are subject to various interpretations. Localized geologic conditions or different business climates may suggest further analysis. [See USGS comments Issue \#4 for response.]

[Cr]-3. Show a confidence interval on any results produced by CoalVal to illustrate that it is a pre-feasibility cost model, and this class of model is generally conceded to produce over all accuracy levels of $+/-25 \%$. Include an option to capitalize new preparation and loadout facilities and eliminate trucking on large reserve blocks of coal in the east and on all longwall mines. [See USGS comments Issue \#5 for response.]

[Cr]-4. Perform a reality check. CoalVal can easily become outdated (and may currently be so), reality checks are needed for the various coal-type models in each region. Two additional output figures may help in this regard. First, CoalVal output should include the saleable tons per man-hour for the model mines; these could be compared to publicly available data for similar mines in each region. Second, the pre- dicted cost for the mines that approach "average" conditions ought to be checked against the latest actual values. This will not be an easy task, but such calibration is essential to achieving credibility. [See USGS comments Issue \#5 for response.]

[Cr]-5. Consider, when time permits, the simplification of the CoalVal model, to minimize the effort of making future updates. [See USGS comments Issue \#5 for response.]

[Cr]-6. Explain, when reporting results, the reasons for the "flattening" effect on the coal resource cost curves associated with regional modeling. [See USGS comments Issue \#5 for response.]

[Cr]-7. Add highwall mining to the models contained in CoalVal. [See USGS comments Issue \#5 for response.]

[Cr]-8. Explain, in the program documentation, what "Mineable Resource Recovery" is and how this rate is established for the various types of mining and each mine. [See USGS comments Issue \#5 for response.]

[Cr]-9. Explain what the assumed productivity rates are (or how they are established) for the various types of mining, and verify these assumptions on a regional/basin basis. [See USGS comments Issue \#5 for response.]

[Cr]-10. Validate preparation plant costs in the East and rail load out costs in the Powder River Basin, both of which appear to be excessive, and explain, in the program documentation, the method of determining these costs. [See USGS comments Issue \#5 for response.]

[Cr]-11. Determine, and correct as needed, the bias introduced into the CoalVal model by modeling only the first ten years of mine costs. [See USGS comments Issue \#5 for response.]

[Cr]-12. Explain, in the program documentation, the method of determining how recovery estimates are established for the various types of mining. [See USGS comments Issue \#4 for response.]

\section{Appendix B - USGS Responses to the Peer Review Committee Report}

\author{
By Timothy J. Rohrbacher, James A. Luppens, Lee M. \\ Osmonson, David C. Scott and Philip A. Freeman
}

\section{Introduction}

Responses to the five principal issues and related recommendations contained in the Peer Review Committee (PRC) Report (Appendix A) are presented herein. As was discussed in a foregoing section, the responses to Issue \#3 (GIS analysis - coal resource characterization), Issue \#4 (GIS mine modeling methodology), and Issue \$5 (CoalVal 2003), each of which is divided into several parts, are keyed to a numbering system that was introduced in Appendix A, and which is applied in 
this section to enable direct cross-referencing. In many cases, a given response addresses more than one PRC issue (i) and (or) recommendation ( $\mathrm{r}$ ) because the topics being discussed have similar themes, which are noted in the response headings.

\section{Responses to the PRC Issues and Recommendations}

\section{Issue \#1 - The Term Reserves}

\section{Responses}

The most contentious observation noted by the PRC dealt with the term "reserves," pointing out that the term "reserves" must be accompanied by some level of mine planning. This allows for the calculation of mining costs that provide a reasonable level of accuracy ( + /- 5 to 15 percent) compared to actual mine costs. USGS reserves studies produce pre-feasibility type mine models and associated mining costs (+/- 15 to 25 percent), however, based on a regional scale rather than a localized mine scale, and therefore "economically recoverable coal resources" analyses may be considered "reserve" estimates. Indeed, the results of these economically recoverable coal resource analyses are the closest accumulated, regional estimates to true USGS, U.S. Bureau of Mines (USBM), U.S. Security Exchange Commission (SEC), and industry-type coal reserves that have been assembled for evaluating U.S. coal deposits. The USGS definition of "coal reserve" from Wood and others $(1983$, p.18) is: "coal resources which could be economically extracted or produced at the time of determination considering environmental, legal, and technologic constraints." The SEC has noted that they use the USGS definition in their analysis (Roger Baer, Security Exchange Commission, oral commun., 2003). A literature search for definitions regarding the term "reserves" (Abbott, 1990; Boyd, 1986; Noyes, 1978; USBM, 1976; USGS, 1983) revealed that the most commonly used reserve definition was "a legally mineable, economically recoverable resource."

The intent of reserves analyses has not been to develop detailed mine plans from the limited amount of public information available. The human and financial requirements needed to produce detailed geologic models and mine plans for such deposits as the Pittsburgh Coal Bed, for example, would require years of work. Regional models of coal stratigraphy and quality, restrictions to mining, and generalized mine and preparation plant recoveries are more logical when assessments are made on a national basis, and the results produce numbers that are relative from one coal region to another. None of the above "reserve" definitions noted the degree of accuracy needed for the definition. Therefore, we have elected to continue to call our coal resource evaluation studies "coal reserve analyses."

\section{Issue \#2 - Revision of the U.S. Geological Survey's Circular 891}

\section{Responses}

Efforts to re-evaluate USGS Circular 891 (Wood and others, 1983) have been ongoing for the past year. One would expect that assurance criteria would vary between coal basins, depending on differences in geological frameworks. As a test, the USGS has acquired detailed data sets from four different coal deposits in the Gulf Coast region to evaluate the modified classification scheme set forth in the revised methodology by determining whether the single criterion currently used to classify geologic resources is valid for the entire country. If this initial work is promising, similar studies will be completed for other coal basins to develop coal-assurance criteria on a regional basis rather than a "one size fits all." A proposal for funding from the USGS's Mendenhall Program to support a post-doctoral research position specifically created to evaluate Circular 891 has recently been submitted; if not approved, tentative plans are for the CEG staff to complete this task.

Several studies conducted during the recent National Coal Resource Assessment (NCRA) investigations attempted to relate the accuracy of stratigraphic correlations and/or coal quality to the amount of data needed to produce a statistically correct geologic model. Although the results of these studies have been published, there continue to be many unanswered questions concerning the reliability of data, that is, how close do data points have to be to accurately predict stratigraphic thicknesses and coal quality? The development of statistical reliability of the data will be part of the task to evaluate and replace or validate the present "reliability arcs" used in Circular 891.

Coincidentally, the Society for Mining, Metallurgy, and Exploration, Inc. (SME) and several international organizations (in Australia, Canada, South Africa, and elsewhere) have begun defining metal, non-metal, and coal resource and reserve categories based on their governmental financial reporting obligations. The CEG participated in several SME-sponsored resource and reserve meetings (coal reserve discussions - most recently in St. Louis, Missouri, September $14,2004)$ where the coal industry, consultants, government, and financial interests were represented. Information from the SME meeting in St. Louis will be merged with data from resource/reserve meetings with metal and non-metal mining companies at the 2005 SME Annual Meeting (J.M. Rendu, consultant, oral commun., 2004) to produce resource and reserve calculation standards. 


\section{External Peer Review of the U.S. Geological Survey Energy Resources Program's Economic Coal Resource Assessment Methodology - Report and Comments}

\section{Issue \#3-GIS Analysis - Coal Resource Characterization}

\section{Responses to Ai-1, Ai-2, and Ar-1 - Methods for Reporting and Calculating Resources}

Concerns that might arise from reporting resources on a total coal-seam basis (new USGS methodology) rather than a coal-only basis (USGS Circular 891 methodology) will be fully addressed in future discussions and publications aimed toward explaining the differences and the relative merits of each methodology to reliably represent in-place resources and reserves. Although stratigraphic information used in USGS coal resource evaluation studies is commonly site-specific, it is generally considered to also be representative of the geology on a regional basis even though local geologic trends such as changing roof conditions and variations in coal-parting thickness and coal quality may not be characteristic for all parts of the region. However, the objective of the USGS coal resource evaluation remains focused on regional models and results rather than local detailed geologic and mine models. Sufficient data are now available to indicate that regional assessments are reliable for the purpose intended, but databases will be continually updated and tested as new assessments are performed. Planned publications will include relevant maps, and data released on the USGS's website and on CD ROMs offer the public the opportunity to look at map layers at different scales.

It is logical that the new reporting method will show larger volumes of in-place resource (when in-seam partings are included). The increase of in-place resources in the Appalachian coalfields is 18 to 24 percent larger using the new methodology compared to the "891 Methodology." This difference comes from: (1) the calculation of unminable resources less than minimum minable bed thickness; and (2) parting material included in the minable seam. This comparison is based on a seam-by-seam comparison within a given study area.

It is recognized that there will always be some uncertainty connected with the terms resources and reserves, and their definitions. For example, Circular 891 states "the thickness of coal used for resource calculations is the net thickness of coal in a bed excluding all partings more than $3 / 8$ inch $(>1$ $\mathrm{cm}$ ) thick." In reality, partings as much as 10 times this thickness generally are impractical to handle selectively from a mining and recovery standpoint. Furthermore, the type of mining equipment planned for use affects the ability to handle thin partings. For example, the use of a surface miner in soft coal allows for the removal of relatively thin partings as opposed to a backhoe or front-end loader working from the top surface of the coal bed. Finally, there is the question of recovered coal quality. If a power plant can tolerate a lower quality product, it may be cost effective to mine the thin parting(s) together with the coal. Each mining scenario results in a different ultimate coal recovery volume. Coal cleaning will further reduce the recovered coal volume. As mentioned previously, the best solution to this problem of adequately defining the resource or the reserve is to provide a clear understanding of the assumptions used in the assessment.

\section{Responses to Ai-3, Ar-2, Ar-6, and Bi-10 - Assessing Reliability and GIS Quality Control}

The new methodology, which includes parting material within the coal beds, is capable of using Circular 891 reliability arcs for modeled coal resources, but it takes more local and regional variations in the geology into account. The arguments for one algorithm versus another in the modeling are many. Equations recommended by the Environmental Systems Research Institute (ESRI) are used and in some cases are tested against the modeling equations of other software.

GIS quality control was briefly addressed in the May 2004 presentations to the PRC. During the development of the MINEMODEL program, calculations and results were checked by modeling all of the mining configurations for two 7.5-minute quadrangle study areas. Mine model layouts were drawn and the polygons digitized by hand. The mine models were then constructed using the same data, and the associated tonnages were calculated using the MINEMODEL program. The differences between the two methods amounted to 1.5 percent and 2.5 percent on the two quadrangle study areas. CoalVal's calculations were checked by: (1) making all the calculations by hand; and (2) where statistics or empirical calculations were necessary, by using other programs as crosschecks.

Post-GIS quality control to determine map resolution and grid resampling errors have not been performed. However, map resolution and accuracy were documented in meta-data and conform to GIS standards. Based on the regional scope of these studies, accuracies of Digital Elevation Models (DEMs) do not need to be more than the 1:24,000-scale of a 7.5-minute quadrangle (Christopher Skinner, oral communications, 2004).

Digital elevation models (DEMs) of 7.5 minute-quadrangles having a 14-m horizontal accuracy were used for the MINEMODEL program. From a property boundary/mine planning/permitting standpoint, greater accuracy is needed, but from a regional or coalfield standpoint the changes in position (accuracy) are not as important when compared to the accuracy of the geological models that a mining company would need to use.

\section{Responses to Ai-4 and Ar-7 - “Data-Poor” Areas and Pittsburgh Coal Bed Modeling}

Coal beds in the central part of the Northern Appalachian Basin should be modeled and reported. Only minimal data were available for Pittsburgh coal bed modeling during the NCRA assessment (USGS, 2001), but many oil and gas and coalbed methane (CBM) wells have been drilled in the basin during the past five years. These data are now available for many coal beds in the upper 3,000 ft of strata. Geologists at Consolidation Coal Company have volunteered to provide data and insight, and geologists at the West Virginia Geologic and Economic Survey (WVGES) are now working on data collec- 
tion. The accumulated data show that the Pittsburgh Coal Bed thins to the south and west from the basin interior into areas of little or no coal (N. Fedorko, WVGES, oral commun., 2004). Information regarding the exact location of the thinning trend or a line limiting the mining has generally been determined by Consol, the WVGES, and (or) consulting geologists, and the findings coincide with the limitation shown in USGS Professional Paper 1625C (U.S. Geological Survey, 2001).

The stratigraphy and coal quality of the Pittsburgh coal bed were described and assessed in detail in the NCRA's Appalachian Basin Coal Assessment (U.S. Geological Survey, 2001, Chapter C). The mining practices and assumptions were addressed by engineers, geologists, and managers during mine visitations in 2004, and will be reviewed in a forthcoming Pittsburgh Coal Bed Resource Evaluation paper.

\section{Responses to Ai-5, Ar-3, Bi-5, Br-7, Bi-11, and Br-11 - Coal Quality}

At present, representative averages for coal quality data on a county-by-county, state-by-state basis exist for most minable coal beds. Such data are presented in USBM Information Circulars 8655, 8678, 8680, and 8693 and are supplemented by data from the USGS's Coal Quality Database. These averages may not show local variations but are adequate for regional studies.

Much information exists on sold coal quality (coal quality as loaded into train cars) on a train-by-train basis, as shipped from mines that produce from a single coal seam. This value, in turn, is related to in-place coal quality, then to washed-coal quality (which may equal shipped quality), and is directly related to market pricing. Knowledge of the mining practices used at the mines, including the amount of out-of-seam dilution taken with the coal, and referencing USBM washability testing and back-calculating preparation plant recovery rates, can provide an estimate of washing recovery rates for a particular coal seam.

The Gillette Coalfield (Ellis, 2002) may be conveniently divided into three areal "pods" of different coal qualities. Resources and reserves will be calculated and reported within each pod and coal quality ranges and averages will be assigned to the resources. Additional coal quality work is being outlined as new data become available to demonstrate that isopleths of sulfur, ash, Btu, and moisture may be developable. This would allow a much more detailed coal quality estimation of resources by areal pod and mining ratio. Sales prices are based in part on coal quality - even the quality by pod will allow better estimates of sales prices (reported in dollars/million Btu's) for CoalVal.

The Pittsburgh coal bed is well modeled with respect to the ranges and averages of its sulfur, ash, and Btu contents, both by state and by county within the Northern Appalachian Basin (U.S. Bureau of Mines, 1974). Average sales prices per county were calculated based on coal quality data from the producing mines provided by Platt's Coaldat database (Platt's, 2004). These data will be summarized in tabular form to compare coal quality by county to sales price in forthcoming papers concerning coal assessments of the Pittsburgh Coal Bed, Illinois Basin coal beds, and the Gillette coalfield.

The Pittsburgh coal resource area could be subdivided into the Ohio River resources and the eastern basin resources (rail and barge); however, assigning the coal quality range and average by state and by county allows for many more combinations and more detail. Some efforts have been made to develop sulfur, ash, Btu, and moisture isopleths for the Pittsburgh Coal Bed, but the available data were generally considered inadequate for this purpose.

The CEG will document references and more fully describe the methodology used to determine average coal quality on a county-by-county basis in the Northern Appalachian Basin. Although there may be some advantages for reporting coal quality on a moisture-free basis, the common coal industry practice is to sell and purchase coal on an asreceived/as-delivered basis (Platt's, 2004, 2005a, 2005b). The new USGS methodology will continue to report coal quality on an as-received basis, following the American Standard Testing and Materials (ASTM) reporting format.

\section{Issue \#4 - GIS Mine Modeling Methodology}

\section{Responses to Ai-6, Ar-4, Ai-7, and Ar-5 - Mining Restrictions}

Barrier distances (thickness) currently being used are the legal distances set forth by the Mine Safety and Health Administration (MSHA) and the Office of Surface Mine Reclamation Enforcement (OSMRE); a 50-ft minimum barrier or buffer is the existing law in some states. However, because of mine disasters in 2002, those laws may be modified to a greater distance. Based on that probability, the buffers (barriers) will be increased to $200-\mathrm{ft}$ in the new USGS methodology. With respect to the recommendation that the USGS establish better guidelines for making decisions about mining restrictions in a given area, such restrictions will continue to be studied so that we may be in a position to advise on continuing or modifying them as opportunities arise.

\section{Responses to $\mathrm{Bi}-1, \mathrm{Br}-1, \mathrm{Bi}-2$, and $\mathrm{Br}-2$ - MINEMODEL Program}

The issue of Auto-Mine Modeling programming documentation is understood by the ERT and the information will be provided in subsequent papers regarding the methodology, mine modeling, and CoalVal.

After the May 2004 peer review meetings, CEG staff visited the Wyoming BLM offices in Cheyenne, Wyoming, for guidance with mine modeling and mining economics in the Gillette coalfield as mining depths increase. Following those meetings, mining companies and consultants were interviewed to gather updated mining cost information and updated openpit designs. It is obvious that multi-mining methods, such as 


\section{External Peer Review of the U.S. Geological Survey Energy Resources Program's Economic Coal Resource Assessment Methodology - Report and Comments}

pre-benching with truck-shovel operations followed by castblasting and dragline stripping, will be needed in the Gillette coalfield. These updated designs have been incorporated into the MINEMODEL program and the CoalVal Gillette Ratio models will be modified to allow pre-benching with truck/ shovel operation followed by cast blasting and dragline stripping to the top of the coal bed.

\section{Responses to Bi-3, Bi-6, Ci-1e, Ci-1j, C-12, Ci-1k, Ci-1m, and $\mathrm{Cr}-2$ - Mine Modeling Assumptions}

It is unlikely that any coal near active mines would be eliminated as reserves, except for the barrier pillars between old and new underground mines or coal adjacent to burn lines or oxidation zones in surface mines. This is a valid concern for all active coal fields. A method to combine parts of logical production units (LPUs) to form additional viable mining units has been developed, but modifications to the MINEMODEL program and to CoalVal have not yet been developed for adding reserves to active operations. It may be possible to add an LPU to the face of all active mining operations, but the consequence would be that all active mines and mines that recently shut down because of the high price of mining and low coal sales price would have to be identified. At present, our mined-out database contains both producing mines and abandoned mines. The best available information for active coal mine operations is held by Regional OSMRE Offices or District MSHA Offices.

Concerning the philosophy of mine modeling from the land surface down, many of the physical restrictions to mining, such as the 40-ft (Kentucky and Virginia) and 15-ft (West Virginia) minimum thicknesses for interburden, are directly applicable to state and federal mining laws. Variances may be obtained if the operator can prove high enough safety factors through rock mechanics studies and past practices. If recoverability of all of the thinner and minor coal beds is disregarded, coal resource assessments would be biased in the direction of too low overall recovery. In fact, many contract mines have been producing in subjacent or superjacent "thinner or minor" beds for the past $30 \mathrm{yr}$ or more, depending on the coal market. During mine visits in August 2004 and in conversations with operators of small mines over the past few years, we observed that many more superjacent mines are being brought into production over thicker-seamed, abandoned mines than we originally anticipated. Thus, due to the depletion of thicker bedded coal resources in the Appalachian coalfields, the by-passed, thinner seams are now becoming important producers.

A reasonable definition of the Minable Resource Recovery "Rate" is given in CoalVal 2.0 (1994). This definition will be reviewed to see if it should be amplified. The subject of recovery rates will be addressed in planned Methodology and CoalVal papers. No "arbitrary" numbers for recovery rates were used for mines or wash plants. Documentation and summary of recovery rates and productivities were first proposed in the early 1990s (Rohrbacher, 1993, 1994) and were updated in 1999 and 2000. These rates were again updated in 2004 during mine visits and will be documented in the new methodology paper.

The question of washing the mined coal, whether produced by surface or underground methods, is one of marketability and economics. Coal washing is done to enhance coal quality, regardless of the mining method. If, during surface mining, the removal of parting material from a coal seam is practical and cost effective, that operation is performed. However, if the parting materials are too thin or too numerous to be removed during mining, and the mined product is too high in ash or sulfur content to be saleable, then washing the mined product may make it marketable. However, if the washing process adds too much expense, the coal will not be mined. This can be said for surface mines regardless of location. For example, if high ash or medium sulfur coal beds are encountered in the Gillette coalfield mines, the coal is wasted with the spoil or left unmined in the pit, resulting in a recovery rate of 90 to 92 percent from 60-to 80-ft-thick coal seams (a potential loss of 6 to $8 \mathrm{ft}$ of coal).

The same type of mining and washing assumptions are employed in underground mining. If the floor and roof, out-ofseam dilution plus in-seam parting dilution produces a mined product that cannot be sold, then coal washing must be done to enhance the coal quality and possibly make the product marketable. Most underground mines in the eastern U.S. wash their coal to reduce ash and sulfur contents and produce a marketable product. Many, but not all, underground mines in the western U.S. produce coals that contain little parting material and are thick enough that the floor and roof material are still in the coal seam (hence, no out-of-seam dilution). Coal wash plants are used at some Colorado and Utah mines to improve the mined-coal quality. We will follow the regular regional practices on an area-by-area basis as closely as possible.

Concerning the suggestion of holding regional peer review meetings, we have been able to give out information at meetings with several different coal companies in attendance, but it has been our experience to rarely have production and cost information given out by industry sources with the competition sitting at the same table. USGS engineers and geologists are able to acquire much more information if we visit a mine and discuss the operations with mine personnel. Additionally, peer reviews conducted on 5-yr increments or at the beginning of major studies may serve to direct or redirect efforts and goals.

Sensitivity analysis on resource and reserve estimates and costs for regional and coalfield-sized evaluations may not be reasonable. The CEG staff agrees that some of our mining costs and productivity estimates are dated and need revision. During May and June and again in August and September of 2004, production and cost data were collected from mines in the Gillette coalfield, the Northern Appalachian coalfield, and from consultants. Revisions to CoalVal are in process. 


\section{Responses to Ci-4 - Coal Transportation}

Trucking distance was calculated from the center of the resource block to the wash plant, not from the middle of the county to the nearest plant. Again, this was not made as clear as it should have been during the Peer Review presentation, but will be better defined in the planned new methodology and CoalVal papers. It has been noted that the break-point for truck haulage versus belt haulage is about 5 to $6 \mathrm{mi}$, depending on the terrain. Conveyors are generally less expensive to construct, own, and operate for distances greater than $6 \mathrm{mi}$, but in some cases where longer distances are involved, underground conveyor systems may become too expensive to ventilate and maintain and truck haulage again becomes the primary choice. These problems and questions are economical concerns and may take care of themselves in future evaluations after capitalization and operating costs for new wash plants are calculated and combined with other considerations for each 10-yr LPU block.

\section{Issue \#5 - CoalVal 2003}

Responses to $\mathrm{Bi}-9, \mathrm{Br}-9, \mathrm{Cr}-1, \mathrm{Ci}-1 \mathrm{a}, \mathrm{Ci}-1 \mathrm{~g}, \mathrm{Cr}-8, \mathrm{Br}-10, \mathrm{Ci}-$ 1h, Ci-1i, Cr-10, Ci-1d, Ci-1f, Ci-1l, and Cr-9-CoalVal 2003 Cost and Production Assumptions

Recoverability assumptions were developed at the USBM after evaluating data (digitized mine maps and interviews with mine management) from more than 150 mines in the U.S. Most coal companies assumed their minable resource recovery rates to be higher than our studies indicated. The real question is for cases where the resource is to be mined by both longwall and room-and-pillar methods - will the coal company also mine the lower value, continuous miner/room-and-pillar (CM) resource? If not, then the total recovery would be less. This is a typical problem in western coals where the beds thicken and thin more commonly than most eastern coals. Documentation of production and recovery rates will be presented in planned Methodology and CoalVal papers, as well as by other means as opportunities arise.

The latest production rates and mining costs used in CoalVal 2003 were collected during mine interviews in 1999 and 2000 and projected forward to 2004 costs using Department of Labor, Labor Statistics Indexes (capital equipment and operating costs were updated in 2004). On the recommendation of the PRC, mines, and consultants in the Appalachian Basin and Gillette coalfields were visited in May, June and September, 2004, and we attended seminars along with mining company personnel and consultants in August of 2004 to obtain current production rates, man-power requirements, mine designs, and mining costs. These new data will be incorporated into CoalVal before further coal resource evaluations are conducted, and the data will be compared to MSHA productivity statistics for general productivity checks. Industry methods and assumptions will be reviewed at least every 3 to 5 yr to correct for industry improvements.

Verification of the productivity and cost assumptions will continue to be done through interviews with coal companies and consultants. References will be documented whenever possible (most companies are willing to provide information anonymously). It is important to note that maintenance and production downtime were built into the productivity rates for each mine model, and maintenance costs accumulated by equipment type in CoalVal. We believe that a separate industry review of these assumptions is not necessary.

Concerning reporting formats, from a USGS standpoint it is better to show the costs as (1) cost/hour rather than cost/ton, and (2) tons/shift rather than tons/man-hour. However, for the user of CoalVal, both numbers/hour and numbers/ton will be displayed. We defined many assumptions, which, when refined and presented in tables, will provide the details requested by the peer reviewers.

Preparation plants in Appalachia and loadout costs in the Powder River Basin (PRB) were actual costs from major operations in those areas. However, it is possible that the costs used were not representative of the entire coalfield or the costs included activities duplicated elsewhere. The eastern preparation plant costs and the PRB loadout costs will be checked and revised if different from the norm in the coalfield.

Responses to $\mathrm{Br}-6, \mathrm{Bi}-7, \mathrm{Br}-7, \mathrm{Bi}-8, \mathrm{Ci}-1 \mathrm{C}, \mathrm{Cr}-11, \mathrm{Cr}-3$, and Ci-1b - Minimum Resource Block Size and Mine Life Assumptions, and Rate-of-Return Calculations

Mine-life and minimum resource "block size" are complex issues and dependent on corporate philosophy. However, the stated goal of the CEG project is to predict the price at which recoverable coal could feasibly be mined in a consistent and efficient manner. It is our desire to identify the least-cost mine model and estimate the cost of mining that drives the modeling decisions. Block size makes little difference from the Appalachian basins to the Illinois Basin or to western coal basins if depreciation and salvage values are handled correctly. The different resource "block" sizes are defined as the quantity of coal that will be mined over the mine life or the LPU for that mine model. The mine life is set to $10 \mathrm{yr}$ for large surface mines (like Gillette coal field mines) and for underground mining (both room-and-pillar and longwall). The mine life is set to $5 \mathrm{yr}$ for smaller surface mines because these operations are less capital intensive and smaller blocks of coal can sustain a mine operation over the mine life. All areas containing less than one LPU will be added to an adjacent LPU, lumped together with other partial LPUs, or designated as "stranded" resources (for example, considered unrecoverable and restricted from mining). Quantities of stranded coal are likely to be small compared to the larger volumes of reserves available for mining.

The coal resource quantity used for the LPU, although not arbitrary, was not defined to the satisfaction of the PRC during the peer review meeting. The LPU quantity was cal- 
culated from mine production assumptions and represents the in-place resource required to operate a mine for the required mine life in order to recover the cost of the capital investment. In future reports discussing coal resource assessment methodology, we will include commentary describing the quantity of stranded coal and how unlikely and/or expensive it would be to mine.

The addition of preparation and loadout facilities to each LPU in the regional infrastructure will allow resources containing less than one LPU (fractional LPUs) to be either hauled or belted to the closest whole LPU and to share in the cost savings. Truck haulage and belt haulage from the partial LPU to the closest whole LPU will have to be calculated, but the system should be more practical.

As pointed out by the PRC, major capital equipment and infrastructure have a much longer depreciation period than 10 yr. We asked two major coal companies how they handled large capital equipment expenditures and were informed that equipment and infrastructure, such as crushing facilities, preparation plants, train loadouts, silos, draglines, large shovels, shop-warehouse-office complexes, and so on, are depreciated on a 20-to 30-yr basis. The PRC has shown in Figure 1 (Appendix A) that only 60 percent of the net present value was recovered in a $10-y r$ depreciation schedule. For that reason, major equipment depreciation will be changed in CoalVal to reflect a longer time period and the salvage value will be used to pick up the remaining un-depreciated values after $10 \mathrm{yr}$ of production.

The PRC was also concerned with the Rate-of-Return (ROR) calculated by CoalVal, wherein the ROR is set by the user. The present methodology used a standard 8 percent ROR in order to provide the public with a consistent measurement for comparison from one regional assessment to another. An 8 percent ROR was chosen after consulting with experts at the National Energy Modeling System at DOE concerning the appropriate weighted average cost of capital (T. Lee, Department of Energy, e-mail, 2004.) The ROR has to be high enough to encourage initial investment and is not a reflection of what would be acceptable under changing conditions after investments have been committed.

We agree that pre-feasibility studies should be within an accuracy range of 25 percent of the actual mining cost. We also believe that CoalVal is capable of developing cost numbers possibly within a $+/-2-3$ percent error depending on the user's assumptions and the availability of detailed data. However, we recognize that geological models generally do not have the amount of data necessary to develop detailed mine plans, nor will the MINEMODEL program produce plans detailed enough to develop and operate a mine. The possibility of using confidence levels to show a range around a value as a solution to giving results in single cost numbers will be pursued.

\section{Responses to Ci-3 and Cr-6 - Resource-Cost Curve}

The PRC has observed that our cost curves are too flat - that is, small increases in the price of coal result in large increases in reserves. The resource-cost curve is only an estimate based on the inputs of our model. Inputs vary from haul zone to haul zone or county to county where there are variations in geologic conditions, coal quality, haulage costs and (or) business environment costs (that is, fees, taxes, tax assessments and (or) rates). At the present time we feel this curve is calculated correctly and, compared to the data input, the result is a relatively flat curve. However, with proposed changes to mine modeling, production and recoverability rates, coal transportation, mining costs, and depreciation, we believe that the curve should be more normalized. Adding confidence intervals around the prices will make the resource-cost curves appear more like the estimates that they are.

\section{Responses to Ci-2, Cr-4, and Cr-5 - Updating Mine Cost and Production Figures}

In our most recent revision to CoalVal (Aug. 26, 2004), we have simplified many of the operations, added Cost of Living Index (COLI) updates for inputs, and revised sold-coal quality calculations. With the guidance and assistance that was received from the Peer Review Committee, the models are being updated so the program foundation will be correct.

The best way to perform cost checks at mines is to first visit and evaluate representative mines, and then to use reputable consulting studies to back up conclusions. These methods were proven viable by the USBM and were used in 2004 to evaluate mines in the eastern U.S. Reference columns will be added in a summary table to all future related reports to compare saleable tons per man-hour with other productivity statistics.

\section{Responses to $\mathrm{Bi}-4, \mathrm{Br}-3, \mathrm{Cr}-7, \mathrm{Br}-4$, and $\mathrm{Br}-5$ - Mine-Cost Model Additions and Modifications}

For areas containing one LMU or more of longwall minable resources, it may be more practical to plan for and capitalize a coal preparation plant, rail line, and rail loadout than to truck a large amount of coal long distances to coal preparation facilities with access to rail. Although this appears practical, the costing of new rail lines will not be included in the mining costs. Economics and local practices will determine if the movement of coal from the mine to coal preparation facilities should be via belt or haul truck.

As noted in our presentation summary, there are several additional mine models that we are planning to develop - the Highwall Miner model to replace the Auger Mining Model is one of those additions. We were able to obtain a considerable amount of information from operators at MINExpo2004 and, after production rates and costs are verified, the USGS MineModel and CoalVal programs will be modified to incorporate the new models. 
The CEG will consider expanding auto-planning capabilities for existing mines. However, we feel at the present time that our economic models address the regional coal resource evaluations without further involving the details of active mines.

\section{References}

Abbott, David M., Jr., 1990, Common misuses of "ore reserves" in press releases and other public disclosure: National Western Mining Conference, Denver, CO, 7 p.

Affolter, Ronald H., Hatch, J.R., Like, K., Gunther, G.L., Andrews, D., Conolly, C., Treworgy, C.G., and Osmonson, L.M., 2001, Results from the coal resource assessments of the Springfield, Herrin, Danville, and Baker coal beds in the Illinois Basin: Society of Mining Engineers annual meeting, February 26, 2001, Denver, CO.

Boyd, James, 1986, Fundamentals of coal and mineral valuations: Chapter 2, Reserves, p2, in C.J. Krehbiel Company, Cincinnati, Ohio, 166 p.

Carter, M.D., Rohrbacher, T.J., Osmonson, L.M., and Molnia, C.L., 2001, U.S. Geological Survey coal availability/recoverability studies program: update 2001: Society of Mining Engineers annual meeting, February 26, 2001, Denver, CO.

Ellis, Margaret, S., and Nichols, D.J., 2001, U.S. Geological Survey 1999 resource assessment of selected coal zones in the northern Rocky Mountains and Great Plain region, Wyoming, Montana, and North Dakota: Society of Mining Engineers annual meeting, February 26, 2001, Denver, CO.

Ellis, Margaret S., 2002, Quality of economically extractable coal beds in the Gillette Coalfield as compared with other Tertiary coal beds in the Powder River Basin, Wyoming and Montana: U.S. Geological Survey Open-File Report 02-174, 19 p.

Haacke, J., Rohrbacher, T.J., Wilde, E., Osmonson, L.M., Scott, D.C., and Luppens, J.A., 2005, Coal bed correlations of the northern Powder River Basin: Society of Mining Engineers annual meeting, March 1, 2005, Salt Lake City, UT.

Luppens, J.A., Osmonson, L.M., Molnia, C.L., Ellis, M.S., Rohrbacher, T.J., Freeman, P.A., and Scott, D.C., 2005, The evaluation of extractable coal resources in the Gillette Coalfield, Powder River Basin, Wyoming: Society of Mining Engineers annual meeting, March 1, 2005, Salt Lake City, UT.
Molnia, Carol L., Osmonson, L.M., Ochs, A.M., Ellis, M.S., Rohrbacher, T.J., and Mercier, T.J., 2002, Evaluation of coal resources in the Gillette Coalfield, Wyoming: Society of Mining Engineers annual meeting, February 25, 2002, Denver, CO.

McIntosh, G., 2003, CoalVal 2001: a computer program to establish economically recoverable resources: Society of Mining Engineers annual meeting, February 25, 2003, Cincinnati, $\mathrm{OH}$.

McIntosh, G., Rohrbacher, T.J., Osmonson, L.M., and Freeman, P.A., 2005, CoalVal 2003 - A coal resource valuation program: Society of Mining Engineers annual meeting, March 1, 2005, Salt Lake City, UT.

Noyes, Robert (editor), 1978, Coal resources, characteristics, and ownership in the U.S.A: Noyes Data Corporation, Park Ridge, N.J., 346 p.

Osmonson, L.M., Rohrbacher, T.J., Luppens, J.A., and Freeman, P.A., 2005, Coal resource evaluation and reserve analysis of the Pittsburgh coal bed, Pennsylvania, West Virginia, Ohio, and Maryland: Society of Mining Engineers annual meeting, March 1, 2005, Salt Lake City, UT.

Pierce, Brenda S., 2001, Coal resources for the future: summary results of the U.S. Geological Survey national coal resource assessment: Society of Mining Engineers annual meeting, February 26, 2001, Denver, CO.

Platts, 2004, Coaldat - coal database: Platts, 3333 Walnut Street, Boulder, CO 80301.

Platts, 2005a, Unified coal pricing methodologies: Platt's, 3333 Walnut Street, Boulder, CO 80301.

Platts, 2005b, Coal outlook: Platt's, 3333 Walnut Street, Boulder, CO 80301.

Rohrbacher, Timothy J., Kirschbaum, M.A., Brownfield, M.E., Carter, M.D., Dubiel, R.F., Fasset, J.E., Hettinger, R.D., Johnson, E.A., Osmonson, L.M., Roberts, L.N., and Scott, D.C., 2001, Geologic assessment and selected economic evaluations of coal deposits in the Colorado Plateau: Society of Mining Engineers annual meeting, February 26, 2001, Denver, CO.

Rohrbacher, Timothy J., Osmonson, L.M., Scott, D.C., and Luppens, J.A., 2005, Economic evaluation of recoverable resources, a methodology: Society of Mining Engineers annual meeting, March 1, 2005, Salt Lake City, UT.

Rohrbacher, Timothy J., Teeters, D.D., Osmonson, L.M. and Plis, M.N., 1994, Coal recoverability and the definition of coal reserves, Central Appalachian Region, 1993: U.S. Bureau of Mines Open-File Report 10-94, 36 p. 
Rohrbacher, Timothy J., Teeters, D.D., Sullivan, G.L. and Osmonson, L.M., 1993, Coal resource recoverability - a methodology: U.S. Bureau of Mines Information Circular 9368, 48 p.

Scott, D.C., Rohrbacher, T.J., Osmonson, L.M., and Carter, M.D., 2003, Results of 202 coal resource evaluation studies in the western and central United States: Society of Mining Engineers annual meeting, February 25, 2003, Cincinnati, $\mathrm{OH}$.

Scott, D.C., Osmonson, L.M., Rohrbacher, T.J., and Freeman, P.A., 2005, Coal resource evaluation and reserve analysis of the Springfield, Herrin, Danville, and Colchester coal beds, Illinois Basin: Society of Mining Engineers annual meeting, March 1, 2005, Salt Lake City, UT.

Suffredini, Charles D., Plis, M.N., Rohrbacher, T.J., and Teeters, D.D., 1994, CoalVal 2.0 - a prefeasibility software package for evaluating coal properties using Lotus 1-2-3, release 3.1: U.S. Bureau of Mines Open-File Report 35-94, $198 \mathrm{p}$.

U.S. Bureau of Mines, 1974, The reserve base of bituminous coal and anthracite for underground mining in the eastern United States: U.S. Bureau of Mines Information Circular $8655,428 \mathrm{p}$.

U.S. Bureau of Mines, 1975, The reserve base of coal underground mining in the western United States: U.S. Bureau of Mines Information Circular 8678, 238 p.

U.S. Bureau of Mines, 1975, The reserve base of coals by sulfur content, Part 1, the eastern States: U.S. Bureau of Mines Information Circular 8680, 537 p.

U.S. Bureau of Mines, 1975, The reserve base of coals by sulfur content, Parts 2, the western States: U.S. Bureau of Mines Information Circular 8693, 537 p.

U.S. Bureau of Mines and U.S. Geological Survey, 1976, Mineral resource classification systems of the U.S. Bureau of Mines and U.S. Geological Survey: U.S. Geological Survey Bulletin 1450-B, 12 p.

U.S. Geological Survey, 1999, Resource assessment of selected Tertiary coal beds and zones in the Northern Rocky Mountains and Great Plains region: U.S. Geological Survey Professional Paper, 1625-A, Discs 1 and 2, Version 1.1.

U.S. Geological Survey, 2000, Geologic assessment of coal in the Colorado Plateau: Arizona, Colorado, New Mexico, and Utah: U.S. Geological Survey Professional Paper 1625-B, Discs 1 and 2, Version 1.0.

U.S. Geological Survey, 2001, Resource assessment of selected coal beds and zones in the Northern and Central Appalachian Basin coal regions: U.S. Geological Survey Professional Paper 1625-C, Discs 1 and 2, Version 1.0.
U.S. Geological Survey, 2002, Resource assessment of the Springfield, Herrin, Danville, and Baker coals in the Illinois Basin: U.S. Geological Survey Professional Paper 1625-D, Discs 1 and 2, Version 1.0.

Wood, G.H., Kehn, T.M., Carter, M.D., and Culbertson, W.C., 1983, Coal resource classification system of the U.S. Geological Survey: U.S. Geological Survey Circular 891, 65 p. 


\section{Appendix C Peer Review Committee Biographies}

\author{
Danrick W. Alexander, PE \\ West Virginia University \\ Morgantown, WV
}

Danrick Alexander began his career in 1971 in prototype mining and slurry haulage equipment development for the Mining Research Department of CONOCO, then the parent company of Consolidation Coal Company. He transferred into the Central Engineering Department of CONSOL in 1980 where he has been involved in new mine development, company valuation, acquisition, due diligence, mine sealing, coalbed methane gas production and storage, mine operation analysis and mine engineering projects. He took early retirement from Consol Inc. in March 2000, completed a Masters Degree in Energy Resources at the University of Pittsburgh School of Engineering and is now teaching and pursuing a Ph.D. in Mining Engineering at West Virginia University.

\section{Michael A. Berdine \\ Peabody Energy Twentymile Coal Company Oak Creek, CO}

Michael Berdine is Manager of Technical Services for Twentymile Coal Company located in Oak Creek, Colorado. He has a B.S. Degree in Mining Engineering and a Masters in Business Administration. He started his engineering career with Bethlehem Mines in 1980 as a maintenance engineer. Since then he has held various positions including head mining and longwall engineer, longwall maintenance supervisor, longwall coordinator and director of subsidence mitigation. In 1998 he accepted a position with Twentymile Coal as a senior mine engineer.

\section{Michael J. Lincoln}

\section{Ark Land Company}

Hanna, Wyoming

Michael Lincoln is Manager of Geology and Exploration in the Western U.S. for Ark Land Company located in Hanna, Wyoming. He has a B.A. Degree in Geology and a Graduate Teaching Certification from the University of Northern Colorado. He has worked for Ark Land since 1987, managing coal exploration and mining projects in Kentucky, Wyoming, West Virginia, Utah, and Colorado. He has an extensive background in coal exploration, mine support, and geologic computer modeling, including surface and subsurface mapping and reserve and burden calculation.

\section{Phillip C. Perlewitz}

U.S. Bureau of Land Management, Wyoming State Office Cheyenne, WY
Philip Perlewitz's 19-year Federal career has been with the Department of the Interior, including sixteen years with the Bureau of Land Management. He has served as Branch Chief for Solid Minerals in the Wyoming State Office since January 2001. Mr. Perlewitz has adjudication, operational, and statewide policy responsibilities for all solid minerals under the Wyoming State Office jurisdiction. Solid minerals include coal, trona, bentonite, gold, diamonds, and sand, gravel, scoria, and other construction aggregates. Mr. Perlewitz directs a staff of ten professionals and coordinates BLM Wyoming's solid mineral activities with other Federal and State agencies. BLM Wyoming's solid minerals annual budget is approximately six million dollars.

\section{Stanley C. Suboleski}

Federal Mine Safety and Health Review CommissionMidlothian, VA

Stanley Suboleski is a Commissioner with the Federal Mine Safety and Health Review Commission, in Washington, DC. He has held numerous positions including Executive Vice President and Interim Chief Operating Officer of Massey Energy Company; Professor and Department Head of Mining and Minerals Engineering at Virginia Tech; Vice President of Operations-Strategy for A. T. Massey Coal Company, Inc.; and President of Massey's United Coal Company subsidiary. He received his B.S. and Ph.D. degrees from Penn State in 1963 and 1978, and his M.S. degree from Virginia Polytechnic Institute in 1967, where he also served as an Instructor. Dr. Suboleski has been active in the Society for Mining, Metallurgy and Exploration (SME) where he held a number of posts, including Chairman of the Coal Division, member of the Board of Directors, and Secretary-Treasurer of the Central Appalachian Section. He is a Distinguished Member of the SME, a recipient of the SME's Howard Eavenson Award, and the AIME's Erskine Ramsey Award. In 2004, he was elected to the National Academy of Engineering.

\section{Gerald Alan Weisenfluh \\ Kentucky Geological Survey \\ Lexington, KY}

Gerald Weisenfluh is Head of the Geospatial Analysis Section of the Kentucky Geological Survey in Lexington, Kentucky. He received his Ph.D. and M.S. Degrees from the University of South Carolina in Columbia, South Carolina and his B.A. from the College of Wooster in Wooster, Ohio. Dr. Weisenfluh has an extensive background in coal and mineral resource evaluation, geographic information systems (GIS) and computer applications for geologic research, resource assessment, and mine related studies. 